\title{
Ethnobotany of suweg (Amorphophallus paeoniifolius): Folk classification, habitat, and traditional conservation in Cisoka Village, Majalengka District, Cimanuk Watershed Region, Indonesia
}

\author{
ASEP ZAINAL MUTAQIN ${ }^{1,2}$, DENNY KURNIADIE ${ }^{2}$, JOHAN ISKANDAR ${ }^{1,2}$, MOHAMAD NURZAMAN $^{1}$, \\ RUHYAT PARTASASMITA ${ }^{1}$ \\ ${ }^{1}$ Department of Biology, Faculty of Mathematics and Natural Sciences, Universitas Padjadjaran. Jl. Raya Bandung-Sumedang Km 21, Jatinangor \\ Sumedang 45363, West Java, Indonesia. Tel.: +62-22-7797712, `email: ruhyat.partasasmita@unpad.ac.id; rp2010rikkyo@gmail.com, \\ asep.zainal.mutaqin@unpad.ac.id \\ ${ }^{2}$ Program of Environmental Science, Graduate School, Universitas Padjadjaran. J1. Dipati Ukur 35, Bandung 40132, West Java, Indonesia.
}

Manuscript received: 17 October 2019. Revision accepted: 16 January 2020.

\begin{abstract}
Mutaqin AZ, Kurniadie D, Iskandar J, Nurzaman M, Partasasmita R. 2020. Ethnobotany of suweg (Amorphophallus paeoniifolius): Folk classification, habitat, and traditional conservation in Cisoka Village, Majalengka District, Cimanuk Watershed Region, Indonesia. Biodiversitas 21: 546-555. Amorphophallus paeoniifolius (Dennst.) Nicolson or suweg is commonly called in Sunadese of West Java as suweg that is a species of tuber growing in many regions of the world, including in the Cimanuk Watershed, West Java Province, Indonesia. A. paeoniifolius usually grows in rural areas of West Java in some agroecosystem types, including the homegarden, garden, and mixed garden system. This plant species, in contrast to other tuber species, such as taro, has not been intensively cultivated by rural community in West Java. Even though A. paeoniifolius has not been intensively cultivated, this plant species in the future have the potential to be used for various purposes for human being. Because A. paeoniifolius, one of plant tubers, has a high resistance to unpredictable environmental changes, such as climate change, pest disruption, and easy to maintain. This study aimed to elucidate the traditional ecological knowledge (TEK) of rural people of Cisoka Village, Cikijing Sub-district, Majalengka District of Cimanuk Watershed, West Java on folk classification, habitat, and traditional conservation of A. paeoniifolius. The method used in this study was qualitative. Field data collection was undertaken by observation and semi-structured interviews or deep interviews with competent informants. The results of study showed that the rural population of Cisoka Village, Majalengka District, has recognized two kinds of Amorphophallus. Firstly, Amorphophallus is a commonly consumed that is called suweg which has scientific name as Amorphophallus paeoniifolius (Dennst.) Nicolson. Secondly, Amorphophallus is recognized as not commonly consumed which is called 'iles-iles' (Amorphophallus variabilis Blume). Both species can be traditionally classified based on morphology (tubers, leaf blade and petioles, and flowers), habitat, utilization, cultivation, and suitability of growing places. Specifically, A. paeoniifolius, grows in various conditions, growing at non-cultivated lands, such as forests and cultivated land, such as homegarden, garden, mixed-garden, and rice fields, or pond edges, but predominantly grows in homegardens and gardens. Some of these lands are hieum or shaded areas and negrak or open areas. A. paeoniifolius starts to grow and develop at the beginning of the rainy season until approaching the dry season, which is characterized by yellowing and falling of petiole. Conservation of $A$. paeoniifolius has been based on tradition is carried out by the rural community through storage/ preparation of seeds, which does not destroy A. paeoniifolius that grows in several types of agroecosystems, and is managed semi-intensively in several types of agroecosystems such as homegardens and gardens.
\end{abstract}

Keywords: Cimanuk watershed, Cisoka village, ethnobotany, suweg

\section{INTRODUCTION}

Plants are one of the resources that are closely related to human life. Plants are managed by humans, including to be used in order to meet their needs (Iskandar 2017). The use of plants in question includes food, health, and industry (Walujo 2011). Management of natural resources, including plants by rural communities, generally involves aspects of integrated socio-economic and ecosystem systems, which are based on belief systems (cosmos) and knowledge systems (corvus) (Toledo 2002; Iskandar 2018).

One species of plant that is often used by humans is Amorphophallus paeoniifolius (Dennst.) Nicolson (elephant foot yam) or in its local language is suweg. A. paeoniifolius or other plants that are often used, generally exist in the built ecosystem, such as in the villages around the watershed which are widely managed by the community, especially in the type of homegarden and garden agroecosystem. A watershed is a land area that is an integral part of a river and its tributaries, which functions to accommodate, store and flow water that comes from rainfall to lakes or to the sea naturally, the boundary on land is the topographic separator and the boundary at sea until with water areas that are still affected by land activities (Government Regulation of the Republic of Indonesia Number 37 of 2012). One of the watersheds that are important for the use of resources, including plants, by the community is the Cimanuk watershed. This watershed covers several districts in West Java, namely Garut, Bandung, Sumedang, Majalengka, and Indramayu. The Cimanuk watershed is one of the national strategy areas, because in this watershed region there are several vital state objects, including the Jatigede Reservoir in Sumedang 
District and the West Java Kertajati International Airport in Majalengka District.

More specifically related to the place to grow $A$. paeoniifolius, Mandal et al. (2016) state that the plant is a plant that is widely spread and cultivated by people in India, Indonesia, and other Asian countries. Yuzammi et al. (2017) states that this plant is widespread in the territory of Indonesia. In addition, Santosa et al. (2017) mention that $A$. paeoniifolius grows in Sumatra, Java, Bali, and Lombok, which are genetically divided into three sub-groups. Specifically, in West Java, A. paeoniifolius grows spreading in several areas of Kuningan District (Santosa et al. 2010).

Each species of plant has certain characteristics that are different from other species. Expression of specificity of which can be seen from the morphological characteristics. In addition, there is diversity or variation in individuals in one plant species. For example, Sulistiyo et al. (2015) state that there are genetic variations in porang (Amorphophallus muelleri B), plants that are related to A. paeoniifolius, which can be caused by factors of adaptation to the environment in which they grow.

In addition to diversity, there are also similarities in common characteristics between species so as to create a kinship that can be collected in a classification. Scientific classification generally refers to the nomenclature of established principles. In addition to scientific classifications, there are also classifications based on population knowledge (folk classification) which generally use mother tongue (Iskandar 2018). More generally, this classification according to the community is a knowledge called local knowledge or traditional knowledge or folk knowledge (Ellen and Harris 2000; Iskandar 2018). Local knowledge is very distinctive, gained from various practical experiences locally and is strongly related to the local environment (Cotton 1996; Iskandar et al. 2018a). In general, local knowledge systems are obtained from the synthesis of information obtained from at least four sources, namely (i) the experience accumulated by an individual or community of residents during history throughout his lifetime and can be passed on from one generation to the next generation by a community cultural group, (ii) various experiences of community individuals are shared socially by members of the same generation or the same group in the community, (iii) experiences are shared by various households or domestic groups in a family, and (iv) certain experiences of each individual, obtained through repetition of annual cycles (natural and productive), and enriched with variations in understanding and various unpredictable conditions associated with it (Toledo 2002; Iskandar 2018).

Humans with their environment have a reciprocal relationship. Humans are one entity with their environment. Humans get a variety of imagination and stories about their environment, including the plants that are often used. With this integralist or ecocentrism concept, humans always pay attention to the balance with the environment, maintain, and even respect available resources based on the knowledge gained during interacting with their environment. A concrete example is the behavior or respect of Sundanese people for rice. Besides utilizing Sundanese people, they also have confidence in the esoteric or spiritual value possessed by rice. Thus, Sundanese people have a piece of in-depth knowledge and maintain rice as a very important personification that is integrated to be done through culture or customs (Iskandar 2017; Iskandar and Iskandar 2011; Hidayat et al. 2020). More specifically, Asih and Kurniawan (2019) mentioned that $A$. paeoniifolius tuber in Bali were used in traditional ceremonies, namely the Upacara Dewasa, Rsi, Manusia, Pitra, and Bhuta Yadnya. This means that the community will preserve the plant, as long as the traditional ceremony or cultural product is still ongoing or carried out.

Based on observations and some literature studies as described above, it is necessary to study ethnobotany $A$. paeoniifolius, especially in Cisoka Village, Cikijing Subdistrict, Majalengka District, which belongs to the Cimanuk Watershed knowledge of the population about folk classification, habitat, and conservation of Sundanese people in Cisoka Village, Cikijing Sub-district, Majalengka District.

\section{MATERIALS AND METHODS}

\section{Study area}

This research was conducted in January-May 2019 in Cisoka Village, Cikijing Sub-district, Majalengka District, West Java Province, which is part of the Cimanuk Watershed (Figure 1). Cisoka is a self-contained village consisting of 3 hamlets, 10 neighborhood residents, and 21 neighborhood units (Government of Cisoka Village 2016). Cisoka Village has an altitude of 611 meters above sea level, an area of $4.15 \mathrm{~km}^{2}$, distance to the Sub-district and district centers are $3 \mathrm{~km}$ and $40 \mathrm{~km}$ respectively, and a population of 1,982 people with a density of $478 / \mathrm{km}^{2}$ in 2018 (Statistic of Majalengka District 2019). Cisoka Village topography consists of plains, hills, and river flows (Government of Cisoka Village 2016). Specifically related to land, Cisoka Village has 194.18 Ha of paddy land, 21.12 Ha of homegarden, 19.5 Ha of moor, 4.9 Ha of pond, 58.07 Ha of community forest, $19 \mathrm{Ha}$ of grazing land, and other 7,43 Ha (Agricultural Counseling Center of Cikijing Subdistrict, Majalengka District 2019). The homegarden is usually planted with various species of annual and annual plants, such as ginger (Zingiber officinale Rosc.), and banana (Musa paradisiaca L.). The garden usually also found a pond, to maintain species of fish such as carp (Osphronemus goramy) and tilapia (Oreochromis niloticus). The garden is usually planted with plants such as guava (Psidium Guajava L), cloves (Syzygium aromaticum (L.) Merr \& Perry), coffee (Coffea arabica L.), and albasiah (Paraserianthes falcataria (L.) Nielsen). Rice fields are planted with rice and secondary cropping patterns or vegetables. In addition to rice planted commodity crops, also during the dry season are often planted plants such as shallots (Allium cepa var. aggregatum L.), water spinach (Ipomoea reptana Poir.), long beans (Vigna sinensis (L.) Savi ex Hassk.), hot peppers (Capsicum frutescens L.), cayenne peppers (Capsicum annuum L.), cucumbers 
(Cucumis sativus L.), and tomatoes (Solanum lycopersicum L.). Forests in Cisoka Village are generally community forests with a number of plants including Hibiscus macrophyllus Roxb. Ex. Hornem, Ficus benjamina L., Ficus elastica Roxb. Ex. Hornem, and bamboo (Government of Cisoka Village 2016; Statistic of Majalengka District 2019; Agricultural Counseling Center of Cikijing Sub-district, Majalengka District 2019).

\section{Procedures}

The research was qualitative in nature using the ethnobotany approach (Albuquerque et al. 2014; Iskandar 2018). Field data collection was carried out by observation and through semi-structural interviews or deep interviews. Observation was carried out by observing various land uses commonly found in A. paeoniifolius, such as homegardens, gardens, ponds, forests, and rice fields. In addition, the researchers observed various activities of the population, such as planting, harvesting, and processing $A$. paeoniifolius tubers. Semi-structured interviews were conducted to find out community knowledge about various aspects of $A$. paeoniifolius, especially related to folk classification, habitat, and conservation. Specifically, semistructured interviews were conducted with informants selected purposively who were considered to be competent by taking into account their diversity, with the snowball technique (Martin 1995; Cotton 1996; Cunningham 2001;
Iskandar 2018). The informants in this study were several elderly male and female farmers; public figure; village head and staff; hamlet head; the owner of the land where $A$. paeoniifolius grows; breeder; and pond owners who usually use A. paeoniifolius.

\section{Data analysis}

Data were analyzed through an emic and ethical approach by cross-checking, summarizing, and synthesizing for later narrative descriptive analysis (Newing et al. 2011; Iskandar and Iskandar 2015; Iskandar 2018). Cross-checking is done to check the validity of data from various informants' information, based on observations and reports. The cross-checking data will then be summarized and synthesized. Then, data from various sources are narrated in a descriptive analysis sequentially.

\section{RESULTS AND DISCUSSION}

Based on interviews with community informants from Cisoka Village, it was shown that the community in the village had traditional ecological knowledge about suweg (Amorphophallus paeoniifolius (Dennst.) Nicolson) such as folk classification, habitat, and conservation which were explained or elaborated on the subtitles below:
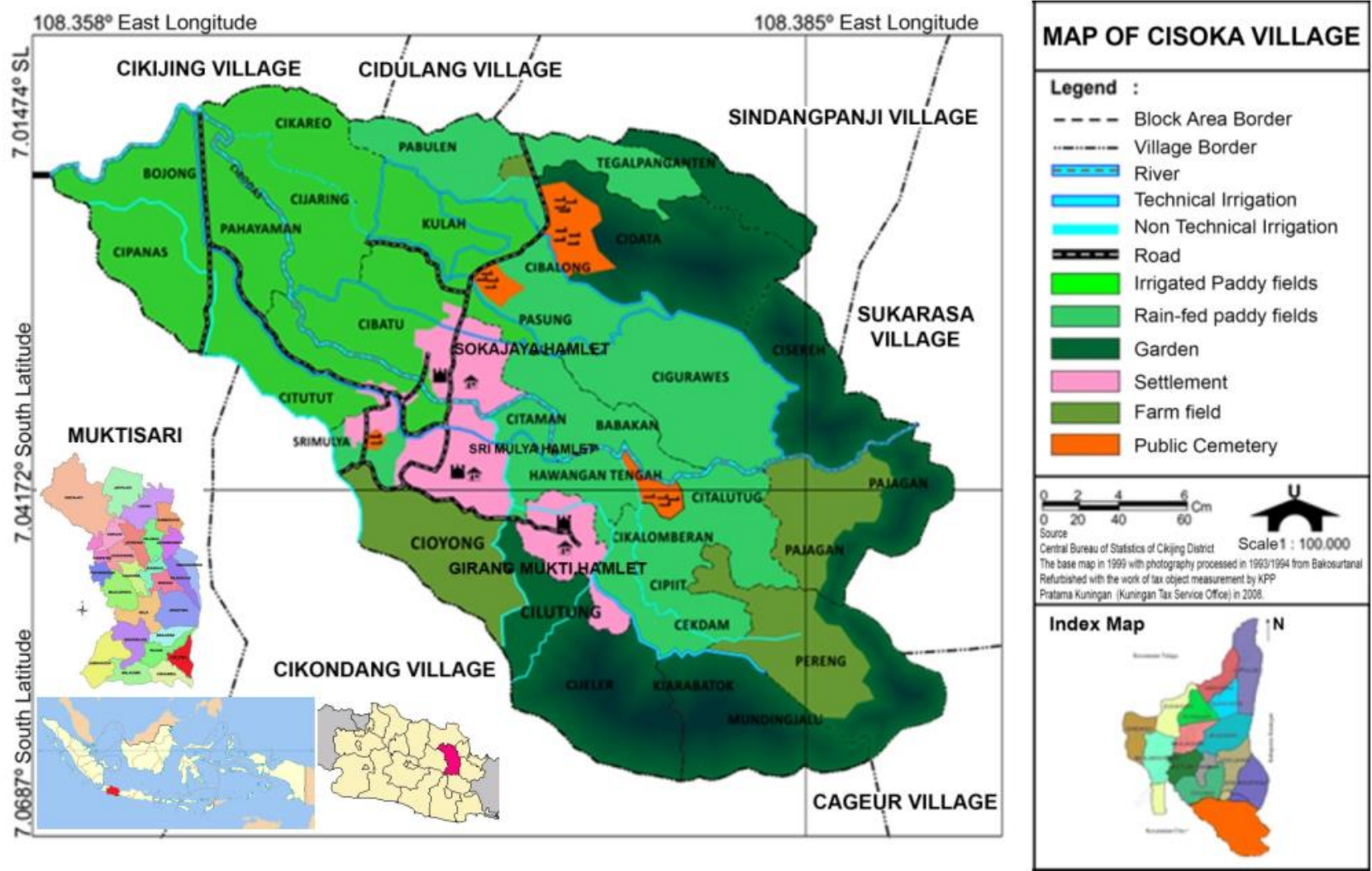

Figure 1. Location of research in the Village of Cisoka, Sub-district of Cikijing, District of Majalengka, West Java, Indonesia (Mutaqin et al. 2018) 


\section{Folk classification Amorphophallus}

According to the rural people of Cisoka Village, Amorphophallus is known for 2 species, namely, first, it is a species of Amorphophallus that is not commonly consumed, commonly called ileus with the scientific name iles-iles (Amorphophallus variabilis Blume). Another type, commonly called suweg, with the scientific name suweg (Amorphophallus paeoniifolius (Dennst.) Nicolson).

Based on the knowledge of the people of Cisoka Village, the two species of Amorphophallus can be classified (folk classification) based on morphology, such as tubers, petioles, and flowers; utilization; hábitat; and cultivation (Table 1 and Figure 1).

As additional information, the community knows that some of the other features of iles-iles are itchy tubers, the color of tuber flesh is white, and the size of a handful. Meanwhile, suweg's tubers have blackish-brown outer shell characteristics; reddish-white or yellowish-white tuber flesh; chewy or soft when cooked; there is a rather sweet taste; rooted and sprout; gummy or slimy colored clear or light yellow or slightly reddish and sticky; spherical round shape, middle grooved; odorless; and weighs as big as a pan or about $10 \mathrm{~kg}$. In addition, the community also knew that in the suweg tubers there were a large number of tubers, round in shape, and a length of up to about $20 \mathrm{~cm}$.

Associated with differences in leaf morphology, the community informed that ileus has a greenish-purple stalk and not rough. Meanwhile, suweg has green leaf stalks with white spots, round in shape, surface, rather rough, gummy or slimy, which are clear and itchy; height can reach around 1-2 meters or in the local language sa tangtung (as high as the human body); 3 (three) branches that together with the leaf blade look like an umbrella shape or rampidak (in local language); and leaflets that are green, but when it is old it turns yellow, marked by the withering of leaves (leaf blade and petiole); hairless, smooth

Associated with differences in flower organs, people know that ileus smells of carcasses. Likewise, suweg has a flower that smells of carcasses. In addition, suweg have red or dark red or pink or brownish-red or blackish red or purple flowers; oval rounded like a banana heart; and not gummy.

Regarding habitat differences, the community knows that ileus grows in forests that are generally tiis (in local language) or cold. The weather or temperature is due to hieum (in the local language) or shaded by higher plants. While suweg can grow in areas that are cold, temperate, or hot in the sense that it can grow in the hieum and negrak areas (in the local language) or open.

Regarding utilization, the community informed us that ileus was generally not used because of itching. Meanwhile, suweg is used for several purposes such as food and feed. Organs that are used as food are tubers. Organs used as food are strands and petioles.

Table 1. Difference between suweg and iles-iles according to the community of Cisoka Village, Cimanuk Watershed Region, Indonesia

\begin{tabular}{lll}
\hline Description of difference & \multicolumn{1}{c}{$\begin{array}{c}\text { Suweg } \\
\text { (Amorphophallus paeoniifolius) }\end{array}$} & $\begin{array}{c}\text { Iles-iles } \\
\text { (Amorphophallus variabilis) }\end{array}$ \\
\hline $\begin{array}{l}\text { Morphology } \\
\text { - Tuber }\end{array}$ & Large tuber & Small tuber \\
- Leaf-blade and petiole & Big and tall & Small and short \\
- Flower) & Rounded bud & Long-form, growing up \\
Habitat & Generally shaded or open areas & Generally, in shaded areas \\
Utilization & Be utilized & Not utilized \\
Cultivation & Cultivated, but not intensive & Not cultivated \\
Suitability of place grow & Diverse & Somewhat limited \\
\hline
\end{tabular}

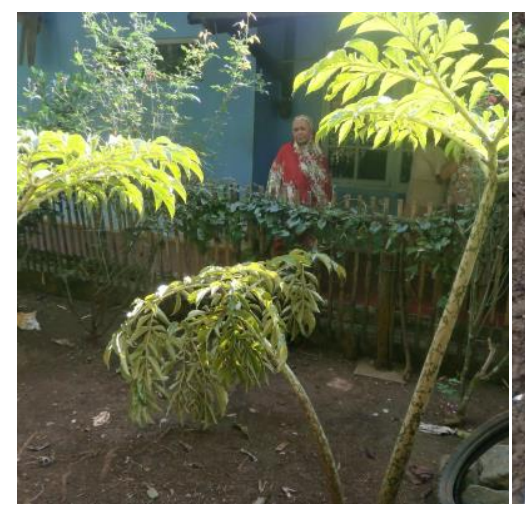

A

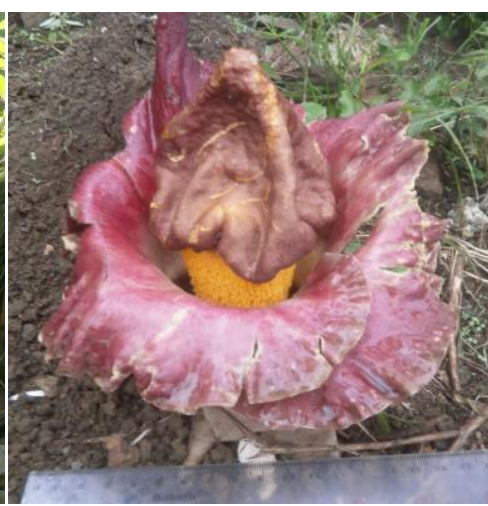

$\mathbf{B}$

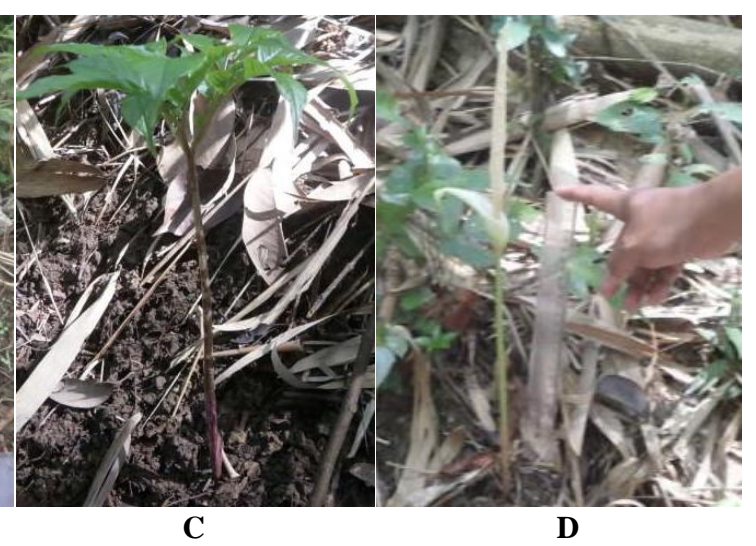

C
D

Figure 2. Differences between suweg (A and B) and iles-iles (C and D) from Cisoka Village, Cimanuk Watershed Region, Indonesia 
Table 2. Some variants of suweg based on petiole, tuber flesh color, and taste according to the people of Cisoka Village, Cimanuk Watershed Region, Indonesia

\begin{tabular}{lll}
\hline Variant category & \multicolumn{1}{c}{$\begin{array}{c}\text { Suweg 1 } \\
\text { (Amorphophallus paeoniifolius) }\end{array}$} & \multicolumn{1}{c}{$\begin{array}{c}\text { Suweg 2 } \\
\text { (Amorphophallus paeoniifolius) }\end{array}$} \\
\hline Petiole & Thin & Not thin \\
Color of tuber meat & Reddish white & Yellowish white \\
The taste of tuber meat & Taste good & Don't taste good \\
\hline
\end{tabular}

Table 3. Some variants of suweg by place of growth according to the community of Cisoka Village, Cimanuk Watershed Region, Indonesia

\begin{tabular}{llll}
\hline $\begin{array}{l}\text { Category of place to } \\
\text { grow }\end{array}$ & \multicolumn{1}{c}{$\begin{array}{c}\text { Suweg 1 } \\
\text { (Amorphophallus paeoniifolius) }\end{array}$} & $\begin{array}{c}\text { Suweg 2 } \\
\text { (Amorphophallus paeoniifolius) }\end{array}$ & $\begin{array}{c}\text { (Amorphophallus paeoniifolius) } \\
\text { (Amerpen } 3\end{array}$ \\
\hline Light intensity & Shade area & Open area & Somewhat open area \\
Soil texture & Silt soil & Clay soil & Sandy soil \\
Soil color & Reddish soil & Blackish soil & Brownish soil \\
\hline
\end{tabular}

Regarding cultivation, the community knows that ileus is a wild plant that is not cultivated at all. Slightly different from suweg, although not intensive, is still planted or allowed to grow on land that is normally managed by the community such as homegardens and gardens.

Regarding the suitability of growing areas, people know that ileus has a rather limited spectrum of growth sites, generally in hieum (shaded) or tiis (cold temperatures). Meanwhile, suweg can grow in a variety of place conditions. Suweg can grow on a flat topography or gawir (land with sloping or slightly sloping elevation). In addition, suweg can grow in a variety of soil conditions, both color, texture, or level of fertility. Likewise, suweg can grow in varying conditions of temperatures or vegetation environments.

In addition to the diversity of Amorphophallus which is classified into two species, although it is not specific and explicitly informs of morphological variations like other plants (taro, cassava, sweet potato, or others), the community informs that there are several variants of suweg based on the petiole, tuber flesh color, taste tuber meat, and growing sites as shown in Table 2 and Table 3.

In addition to information, the community informed that there are some differences growth of suweg in different conditions or places. Suweg that grows in shaded areas or hieum (in the local language) have thin petiole or jangleung (in the local language). Conversely, suweg that grows in open areas or negrak (in the local language) has a petiole that is not thin. According to the community, jangleung petiole because it is less exposed to sunlight or panon poe (in the local language). In addition, tubers that have a good taste or pulen (in the local language) are cooked tubers derived from tubers harvested during the dry season. Whereas the tubers which are harvested at the time of growth or the petiole do not yet fall have a bad taste or cangor (in local language).

Based on literature review as a comparison with public knowledge about nomenclature, specifically $A$. paeoniifolius, this plant has several local names including kidaran in Sabaramaguwa-Sri Lanka Province
(Dharmadasa et al. 2016); karnai kizhangu in the Namakkal-Tamilnadu District (Ramanathan et al. 2014); karnaikilangu in Kerala-India (Yabesh et al. 2014); and koniaku in Japan, buk khan in Thailand, and suvarna gedde in Canada (Singh and Wadhwa 2014). In general, the diversity of names or knowledge is influenced by ethnicity, gender, and age (Zambrana et al. 2014). Furthermore, specifically, Adnan and Othman (2012) stated that knowledge of plant identification in rural areas is higher than in urban areas.

Public knowledge about the differences in places to grow between suweg and iles-iles (Table 1), is in line with what was concluded by Siswanto and Karamina (2016) that the parameters of land requirements for the species of members of the genus Amorphophallus are not all the same. Yuzammi et al. (2017) also inform that the habitat and distribution of Amorphophallus species are varied. Specifically, Nugraha et al. (2018) found a suweg in the mountainous region. Meanwhile, Afifah et al. (2014) state that the conditions for growing iles-iles plants are under a shade at least $50 \%$ with temperatures around $22-30^{\circ} \mathrm{C}$.

Amorphophallus diversity in Cisoka Village as mentioned by the community is in line with what was informed by Supriati (2016) that in Indonesia there are generally several species of Amorphophallus such as Amorphophallus oncophyllus Prain ex Hook. f. (iles-iles), Amorphophallus campanulatus (Roxb.) Blume (suweg), and Amorphophallus variabilis Blume (acung). Yuzammi et al. (2017) state that in Indonesia there are several species of Amorphophallus such as Amorphophallus paeoniifolius (Dennst.) Nicolson (suweg), Amorphophallus muelleri Blume (porang), and Amorphophallus variabilis Blume. Specifically, related to diversity, Santosa et al. (2018) states that genetic distance between populations increases with increasing geographical distance.

Associated with the variance or diversity based on morphologists as known to the public in line with several scientific sources. Anil et al. (2011) state that morphological characters such as cormel shape, cormel weight per corm, fresh corm weight, corm flesh color, and 
petiole surface pattern can be used for the identification of various morphotypes of Amorphophallus paeoniifolius. In addition, Santosa et al. (2012) concluded that there are groupings of accessions of Amorphophallus variabilis Blume based on morphological groups. Ekowati et al. (2017) also mentioned that phenetic or morphological characters such as leaf blades, petiole, and tubers can be used as a basis for the classification of Amorphophallus.

Associated with public knowledge that plants have characteristics based on morphology in line with some of the results of scientific studies. Permatasari et al. (2014) state that plant characteristics can be identified based on morphological, anatomical, and isozyme banding patterns. More specifically, Priyanti et al. (2013) state that plant characteristics can be analyzed based on the morphological character of the petiole.

In more detail, the morphological characteristics of ileus and suweg knew to the community are in line with some of the results of scientific studies. The results of searching for several scientific sources related to the characteristics of the Amorphophallus variant, specifically Amorphophallus variabilis Blume has characteristics of tuber diameter is commonly small, about $10-15 \mathrm{~cm}$, very dark, rough, producing seasonal rhizomatous buds. Petiole $50-75 \mathrm{~cm}$ long and up to $120 \mathrm{~cm}$, smooth, sometimes glossy, variegated surface color from pale green, greenishbrown, pure green to pale brown, with randomly whitishgreen to dark green irregular spots. Blade or blade 50-75 $\mathrm{cm}$ in diameter and up to $125 \mathrm{~cm}$; almost similar to $A$. paeoniifolius lamina, elliptical to lanceolate leaflets, 4-34 $\mathrm{cm} \times 2-12 \mathrm{~cm}$. Peduncle about $50-60 \mathrm{~cm}, 1-2 \mathrm{~cm}$ in diameter. Inflorescence is the longest than A. muelleri and A. paeoniifolius; spathe narrowly short, up to $20 \mathrm{~cm}$ or $1 /$ 3-1 / 4 spadix length, limb pale green-green with randomly whitish spots outside, creamy white-ivory inside. Spadix is commonly very longer than spathe. When inflorescence is flowering, it's commonly known with a bad smell that appears early in the evening. Only unripening infrastructure found during fieldwork, cylindrical, densely arranged, green; the ripening fruit is orange-red with 1-3 seeded (Jansen et al. 1996; Kurniawan et al. 2011). In addition, Pratama (2011) states that this plant has several characteristics including the green to brownish green petiole, plain patterned to have rounded or oval-shaped patches of white to yellowish, smooth surface, length ranging from $5.2-160 \mathrm{~cm}$, diameter $0.05-2.3 \mathrm{~cm}$; tubers between $7.5-12.7 \mathrm{~cm}$ in diameter, white tuber flesh with tuber skins brownish-white, there are several buds; spatha in yellowish-green inflorescence, the lower speckled with various shades, having a length of about $5-22.4 \mathrm{~cm}$, diameter 1.3-4.1 cm; yellowish-white male flowers up to brown, 2.2-6.8 cm long, 1.1-3.1 cm in diameter; and female flowers are yellow on the head of the green bottom, $2-5 \mathrm{~cm}$ long, 1.1-2.8 cm in diameter.

Meanwhile, according to several scientific sources, $A$. paeoniifolius has several morphological characteristics related to the organs of leaves, tubers, flowers, and roots. A. paeoniifolius has complete leaf (has petioles, vagina, and lamina), compound leaves, leaf reinforcement pinned to the sharing edge, has 6-8 leaflets, and is elliptical with a tapered tip. Leaf blade of $A$. paeoniifolius is light green to dark green, with a smooth surface. The petiole is light green to dark green and has a white bottle, speckled surface, divided into three secondary stems, $3.3-10 \mathrm{~cm}$ in diameter, and 75-100 cm in length (Jintan et al. 2015); petiole dark green, light green, light greenish-yellow, and brownish-green (Permatasari et al. 2014); leaves 100-150 $\mathrm{cm}$ in diameter, highly fragmented oval-shaped oblong and winged rachis, petiole such as warty-thorny and grooved folding, dark brown-greenish brown in wild species and slightly wintered-spiny or smooth, pale green- green on the type of cultivation with whitish green dots in both wild and cultivated species (Kurniawan et al. 2011); pale green up to dark green or black-green petiole with small and largesized patches, stems reaching 2 meters in height, and $20 \mathrm{~cm}$ in diameter (Yuzammi et al. 2017); the petiole is usually strongly warty, rarely smooth, always blotched and never striped (Sedayu et al. 2010). Brownish-yellow tubers (Jintan et al. 2015); dark brown, up to $15 \mathrm{~kg}$ in weight (Yuzammi 2017); tuber skin is blackish brown, tuber flesh is purplish yellow, and has a petiole diameter of $20-25 \mathrm{~cm}$ (Govi et al. 2017). A. paeoniifolius flowers are large and give off a scent like a carcass, a sheath measuring 10-30 x $15-50 \mathrm{~cm}$ with an upper sheath surrounding the cob, the cob is longer than the sheath, the outer sheath is palebrown green with pale green-whitish dots, the inner shell of a dark brown shiny-red purplish heart, and has a shorter stem than the petiole and elongates when bearing fruit (Kurniawan et al. 2011); the smell of rotten meat (Kite and Hettersceid 2017). Root of A. paeoniifolius is root spreading (Singh et al. 2010); cylindrical shape, growing horizontally extending to more than $1 \mathrm{~m}$ during the rainy season, whereas in the dry season the length is up to less than $30 \mathrm{~cm}$ and its thickness is 2-5 mm (Ravi et al. 2009); root length up to about 50-60 $\mathrm{cm}$ (Govi et al. 2017).

Associated with public knowledge about differences in places to grow there are causing some differences in characteristics, this is in line with some scientific research results. Heriyansyah et al. (2017) state that there are variants of suweg (A. paeoniifolius) based on differences in growing locations. Likewise, Sulistiyo et al. (2015) mentioned that there is a variant of porang (Amorphophallus muelleri Blume), a plant that is related to suweg, based on differences in growth location. More specifically, Sahoo et al. (2016) revealed that light intensity influences vegetative growth of plants such as plant height and canopy width. In addition, Wijayanto and Pratiwi (2011) revealed that the shade affects the growth of porang (Amorphophallus onchophyllus), plants that are related to suweg, such as tuber wet weight, tuber diameter, biomass, and plant height.

Related to community knowledge which mentions several different soil textures and colors is as a medium to grow A. paeoniifolius, this is in line with the results of other studies related to community knowledge about the classification of land-based on color (Iskandar et al. 2018b). Permatasari et al. (2014) state that A. paeoniifolius are found in loose, silty, and sandy silt. Furthermore, Daryanto et al. (2016) inform that soil texture is generally related to production capacity and groundwater. In 
addition, soil conditions, especially $\mathrm{pH}$, affect the distribution of Amorphophallus (Hafsah et al. 2018).

Table 4. Habitat of suweg based on vegetation cover and land use according to the people of Cisoka Village, Cimanuk Watershed Region, Indonesia

\begin{tabular}{ll}
\hline Habitat category & Habitat type \\
\hline $\begin{array}{l}\text { Non-cultivation land } \\
\text { type }\end{array}$ & Forest \\
Cultivation land type & $\begin{array}{l}\text { Homegarden, garden, rice field edge, } \\
\text { pond edge }\end{array}$ \\
\hline
\end{tabular}

Table 5. Growth of suweg according to the people of Cisoka Village, Cimanuk Watershed Region, Indonesia

\begin{tabular}{ll}
\hline Organ & Time of growth \\
\hline Leaves & $\begin{array}{l}\text { Early rainy season or kapat (in local language)/ } \\
\text { cold weather until before the dry season }\end{array}$ \\
Flower & $\begin{array}{l}\text { Early rainy season or kapat (in local language) / } \\
\text { cold weather }\end{array}$ \\
Tuber & Rainy season \\
\hline
\end{tabular}

\section{Habitat and growth properties of Amorphophallus paeoniifolius}

The rural community of Cisoka Village knows that the habitat or place to grow $A$. paeoniifolius can be distinguished by land as can be clearly seen in Table 4 . The community also knows that $A$. paeoniifolius has several growth characteristics as can be seen in Table 5 .

As additional information, the community knows that the forest is non-cultivated land because it is not or rarely managed to be cultivated for other species of crops. Meanwhile, the homegardens, gardens, rice fields, and ponds are land that is often managed by the community, planted by several species of cultivation plants, either annual or annual crops such as rice, cayenne pepper, tomatoes, onions, bananas, and guava. These lands are very closely related to the fulfillment of daily needs.

Furthermore, the community also knows that forest land is generally hieum area (in the local language). Homegardens and ponds are generally negrak or rather negrak (in local language). Paddy fields are generally negrak area. Meanwhile, garden land, in general, is a hieum or somewhat hieum area. The hieum is an area where sunlight does not enter the land because it is covered with tall tree leaves, poek (in the local language) or rather dark, air or temperature is tiis (in the local language) or cold or rather cold compared to a negrak or open area. Meanwhile, the negrak area is an area where sunlight can enter land or soil, the weather or the temperature is hot or rather hot compared to the hieum or enclosed area.

The community informed that in general, $A$. paeoniifolius grew on lands managed by the community such as homegardens and gardens. But there are also those that grow half-wild on unmanaged lands such as forests. $A$. paeoniifolius that grows in the homegarden, pond edge, and rice field edge, in general, can grow well. Tuber of $A$. paeoniifolius is big and petiole is not thin. Meanwhile, A. paeoniifolius that grow on garden land or grow half-wild in the forest, generally have thin petiole or jangleung and tubers are not as large as those that grow in open areas or negrak.

Related to the relationship with several other species of plants that exist around $A$. paeoniifolius, the community knows that $A$. paeoniifolius can grow with plant species, both cultivated plants (such as cassava or Manihot esculenta Cranz and taro or Colocasia esculenta (L.) Schott) or non-cultivated plants (such as Cyperus rotundus L., Eleusine indica (L.) Gaertn, and Commelina benghalensis L.). However, people know that $A$. paeoniifolius lack or do not grow optimally when covered by vines (such as Piper betle L.) or reeds (Imperata cylindrica (L.) P. Beauv).

Associated with the growth and development of organs, the community knows that the leaf buds come from tubers, child tubers, or skin peeled tubers. Buds grow taller and differentiate or bloom or ligar (in the local language) into leaf blades and petioles. The period of growth of buds to adulthood will end with a marked yellowing of leaf blades and petioles, then withered or fallen. During the dry season, the leaf blades and petioles do not grow. Flowers bloom around 6-30 days. After the blooming period is over, the flower will rot, smell the corpse, then the seed that becomes or raises the flower in the following season will grow into leaf buds. Meanwhile, the tubers during the dry season do not increase in size and bring out the leaf buds.

Knowledge of the community about A. paeoniifolius's habitat is in line with several scientific sources. Yuzammi et al. (2017) state that $A$. paeoniifolius has a wide distribution such as growing on secondary forests, forest edges, teak forests, and village groves. Hidayat (2019) also mentioned that $A$. paeoniifolius grows in the teak plantation forest. Likewise, Restiyadi (2012) states that most of tubers including A. paeoniifolius can grow on various types of land, both fertile or infertile land. Meanwhile, Permatasari et al. (2014) states that A. paeoniifolius are found in areas with open or shaded environments.

Specifically related to public knowledge that shoots or flowers will appear in the kapat season, this can be rationalized with the results of several scientific studies. Hidayat et al. (2013) state that this season is marked by the presence of winds from the west that cause rain. Thus, this phenomenon is influenced by water availability. Ravi et al. (2011) state that the growth of plants in between can be influenced by the availability of water and nutrients. Ravi et al. (2015) state that water deficits affect growth and productivity of Amorphophallus. Mabhaudhi et al. (2013) state that plant height, number of leaves, and leaf area index are affected by the water content in the growing media. Meanwhile, as informed by the public that $A$. paeoniifolius does not experience growth during the dry season, this is in line with scientific information that generally Amorphophallus experiences a period of dormancy starting at the beginning of the dry season. $A$. paeoniifolius will experience an earlier period of dormancy with limited irrigation (Santosa et al. 2004; Santosa et al. 2014). In contrast, Amorphophallus that grows with enough 
water does not have a period of dormancy (Zhang et al. 2010; Santosa et al. 2014).

Related to public knowledge that A. paeoniifolius can grow with any species of plant, this can be analogous to the results of other studies that Rafflesia meijerii, plants that are related to $A$. paeoniifolius, can grow and develop on various types of land cover by several species of plants (Simamora et al. (2017). Permatasari et al. (2014) state that plants that grow around $A$. paeoniifolius have shrubs or trees. More specifically, Jata et al. (2018) concluded that $A$. paeoniifolius can be planted with other plants with intercropping systems. Chandra (2014) also mentions that A. paeoniifolius is good intercropping plants.

Public opinion which states that A. paeoniifolius cannot grow optimally if covered by vines or reeds, in line with the results of scientific research. Kuamr et al. (2019) mentioned that weed disturbance results in slow growth and lower leaf area, which might influence the assimilation production needed for tuber development.

\section{Traditional conservation of Amorphophallus paeoniifolius}

Based on the opinion of the informants of Cisoka Village residents there are several characteristics of the community that can play an important role in the conservation of A. paeoniifolius in rural ecosystems, such as storage/ preparation of seeds, not destroying $A$. paeoniifolius that grows in the type of agroecosystem, and managed in semi-intensive in several types of agroecosystems.

Regarding the storage or preparation of seeds, the community is aware that the storage or safeguarding of seeds is done by letting the tubers of $A$. paeoniifolius are not used during the harvest season concerned buried in the ground. Bulbs that are not harvested are even reversed their position so that the next season will grow bigger. Seed protection is also carried out by the community by deliberately spreading skin peeled tuber that has been used on lands managed by the community such as homegardens or gardens. The community also sometimes removes puppies of suweg or petetan (in local language) from one land to another desired land.

The community informs that the growing $A$. paeoniifolius is not destroyed by allowing or not disturbing or not harvesting the tubers of A. paeoniifolius if it is not needed, both those that grow around the cultivation plant or grow solitary/ clustered without any cultivation plants around it. This is different from disturbing plants or weed plants, such as some species of grass, herbs, or shrubs, which are unwanted to grow around the staple crop cultivation, people usually eliminate these disturbing plants by pulling or weeding.

Regarding management or cultivation, the community knows that $A$. paeoniifolius is not cultivated intensively which is done in the homegardens, gardens, ponds edge, or rice fields, but generally in the homegardens or gardens. Cultivation of $A$. paeoniifolius is very simple which includes planting or spreading seeds, fertilizing, and caring. Planting seeds is done by burying seeds that come from skin peeled tubers, tubers child, or tubers in a hole that matches the size of the seed. Fertilization is done by providing manure, either directly on plant $A$. paeoniifolius or indirectly through plants that are around $A$. paeoniifolius. Fertilizing $A$. paeoniifolius by using chemical fertilizers is never or rarely done. But $A$. paeoniifolius get nutrition from fertilizer given to the surrounding plants. A. paeoniifolius is rarely treated specifically or routinely through the control of pests or diseases such as other cultivating plants in the vicinity. However, if grass or other nuisance plants grow around $A$. paeoniifolius, then the community is often ngored (in the local language) or weeded. Control of pests or diseases of crops that exist around A. paeoniifolius, also indirectly can control pests or diseases that might attack A. paeoniifolius.

The patterns or behavior of the people towards $A$. paeoniifolius, based on their knowledge, as mentioned above are in line with the rules of conservation based on several scientific sources. In general, Iskandar (2017) mentions that social, economic, and cultural aspects of society are important in conservation efforts. For example, there are various taboos in Sundanese society such as buyut, cadu, taboo, and pamali to prevent various human actions that are not in accordance with the environment (Iskandar 2018). Another thing, Hamilton (2013) states that public knowledge about plants is very valuable in conservation. Whitney et al. (2016) state that indigenous peoples' local knowledge and experience are effective or important in biodiversity conservation. Amusa et al. (2010) revealed that the management and utilization of resources by the community provided strong incentives for conservation. Whitney et al. (2018) state that an important place for agrobiodiversity conservation is the homegarden. In addition, Yuzammi et al. (2014) revealed that land conversion or plant commodity conversion in land use can damage the habitat of Amorphophallus discophorus, plants that are related to A. paeoniifolius, which live on the land concerned. Specifically, Yuzammi (2018) informed that Amorphophallus, including A. paeoniifolius, was ex situ conservation through cultivation.

Based on the results of this study it can be concluded that the rural people of Cisoka classifies (folk classification) Amorphophallus into 2 groups or species. The first species is a species of Amorphophallus that is not commonly consumed, commonly called ileus with the scientific name iles-iles (Amorphophallus variabilis Blume). The second species is called suweg, with the scientific name 'suweg' (Amorphopallus paeoniifolius (Dennst.) Nicolson). Suweg and iles-iles can be classified by the community based on morphology (tubers, leaf blades and petioles, as well as flowers), habitat, utilization, cultivation, and suitability of growing places. Specifically, suweg, grows in a variety of conditions, growing on noncultivated lands such as forests and cultivated land such as homegardens, gardens, rice fields, or pond edges, but generally grows in homegardens and gardens. Some of these lands are hieum or shaded areas and negrak or open areas. Suweg starts to grow and develop at the beginning of the rainy season until approaching the dry season, which is characterized by yellowing and falling of petiole. Conservation based on tradition is carried out by the rural 
community through storage/ preparation of seeds, does not destroy the suweg that grows in some types of agroecosystems, and is managed semi-intensively in some types of agroecosystems, including homegardens and gardens.

\section{ACKNOWLEDGEMENTS}

The authors would like to thank everyone or stakeholders who have supported this research, especially Rector of Padjadjaran University, Dean of Postgraduate School of Padjadjaran University, the Head of Program of Environmental School of Postgraduate School of Padjadjaran University, the Head of Cisoka Village, and many people in Cisoka Village. This research was supported by Academic Leadership Grant number: 3369/UN6.D/LT/2019 of Prof. Johan Iskandar.

\section{REFERENCES}

Adnan N, Othman N. 2012. The relationship between plants and the Malay culture. Procedia 42: 231-241.

Afifah E, Nugrahani MO, Setiono. 2014. Prospect of iles-iles (Amorphophallus spp.) as an Intercrop in hevea plantation. Warta Perkaretan 33(1): 35-46 [Indonesian]

Albuquerque UP, Ramos MA, de Lucena RFP, Alencar NL. 2014 Methods and Techniques to Collect Ethnobiological Data. In Albuquerque UP, Cruz da Cunha LVF, Paiva de Lucena RF, Alves RRN (eds) Methods and Techniques in Ethnobiology and Ethnoecology. Springer Science + Business Media, New York.

Amusa TO, Jimoh SO, Aridanzi P, Haruna M. 2010. Ethnobotany and conservation of plant resources of Kainji Lake National Park, Nigeria. Ethnobot Res Appl 8: 181-194.

Anil SR, Siril EA, Beevy SS. 2011. Morphological variability in 17 wild elephant foot yam (Amorphophallus paeoniifolius) collections from southwest India. Genet Resour Crop Evol 58(8): 1263-1274.

Asih NPS, Kurniawan A. 2019. Bali Araceae study: diversity and potential. Widya Biologi 10(02): 135-147 [Indonesian]

Central Statistics Agency of Majalengka District. 2019. Cikijing district in figures. Central Statistics Agency of Majalengka District, Majalengka. [Indonesian]

Cikijing District Agricultural Counseling Center. 2019. BPP agriculture counseling program in Cikijing District. Cikijing District Agricultural Counseling Center, Majalengka [Indonesian]

Chandra KK. 2014. Evaluation of growth and economic parameters of Curcuma longa and Amorphophallus paeoniifolius intercrops in medium aged Psidium guajava orchard. Caribbean J Sci Tech 2: 392 398.

Cotton CM. 1996. Ethnobotany: Principles and Applications. John Willey and Sons.Ltd, England.

Cunningham AB. 2001. Applied Ethnobotany: People, World Plant Use \& Conservation. Earthscan, London.

Daryanto S, Wang L, Jacinthe PA. Drought effects on root and tuber production: a meta-analysis. Agri Water Manag 176: 122-131.

Dharmadasa RM. Akalanka GC. Muthukumarana PRM. Wijesekara RGS 2016. Ethnopharmacological survey on medicinal plants used in snakebite treatments in Western and Sabaragamuwa Provinces in Sri Lanka. J Ethnopharm 179: 110-127.

Ekowati G, Praptomo DW, Rodliyati A. 2017. The phonetic relationships of Amorphophallus sp. Based on their morphological characteristics in Laren Sub-district, Lamongan District. AIP Conference Proceedings 1908, 040010 .

Ellen RF, Harris H. 2000. Introduction. in RF Ellen, P. Parkes, A. Bicker (eds) Indigenous Environmental Knowledge and its Transformation: Critical Anthropological Perspective. Hardwood Academic Publisher, Amsterdam.

Govi DK, Andalil R, Sundaramoorthy B, Narayana SKK, Parameswaran SR. 2017. Comparative macro-microscopic atlas of two aroids used in Siddha medicine. J Ayu Med Sci 2(4): 256-260.
Hafsah, Azrianingsih R. Masri M. 2018. Map of edible Araceae based on abiotic factors in Gowa District, South Sulawesi. J Environ Eng Sustain Tech 5(2): 52-60.

Hamilton A. 2013. New developments in plant conservation and the relevance of ethnobotany. Plant Divers Resour 35(4): 424-430

Heriyansyah F. Soetopo L. Saptadi D. 2017. Exploration and identification of the morphological characteristics of the Suweg plant (Amorphophallus campanulatus BI) in East Java. J Produksi Tanaman 5(3): 377-382. [Indonesian]

Hidayat RT. Haerudin D. Muhtadin TAN. Darpan, Sastramidjaja A. 2013. Sundanese Arts. PT Kiblat Buku Utama, Bandung [Indonesian]

Hidayat S. 2019. Short Communication: The study of suweg (Amorphophallus paeoniifolius) and other undergrowth species in teak plantation forest of Temengeng, Blora, Indonesia. Biodiversitas 20(1): 37-42.

Hidayat RA, Partasasmita R, Iskandar J, Gunawan B. 2020. Changes in paddy field management in Sindang Hamlet, Rancakalong Village, Sumedang District, West Java, Indonesia. Biodiversitas 21(1):98-105

Iskandar J, Iskandar BS. 2011. Sundanese Agroecosystem. PT Kiblat Buku Utama, Bandung. [Indonesian]

Iskandar J, Iskandar BS. 2015. Ethnobotanical study on food crop diversity in swidden agroforestry agriculture to support food security of Baduy community. Prosiding Seminar Nasional Masyarakat Biodiversitas Indonesia 1(6): 1265-1272 [Indonesian]

Iskandar J. 2016. Ethnobiology and cultural diversity in Indonesia. Umbara 1(1): 27-42 [Indonesian]

Iskandar J. 2017. Human Ecology and Sustainable Development. Revised Edition. Program Studi Magister Ilmu Lingkungan, Universitas Padjadjaran, Bandung. [Indonesian]

Iskandar J, Iskandar BS, Partasasmita R. 2018a. Review: The impact of social and economic change on domesticated plant diversity with special reference to wet rice filed and home-garden farming of West Java, Indonesia. Biodiversitas 19 (2): 502-524

Iskandar J. Iskandar BS, Partasasmita R. 2018b. Site selection and soil fertility management by the Outer Baduy People (Banten, Indonesia) in maintaining swidden cultivation productivity. Biodiversitas 19 (4): 1334-1346

Iskandar J. 2018. Ethnobiology, Ethnoecology, and Sustainable Development. Plantaxia, Yogyakarta. [Indonesian]

Jansen PCM, van der Wilk C, Hetterscheid WLA. 1996 Amorphophallus Blume ex Decaisne. In: Flach M, Rumawas F (eds). Plant Resources of South-East Asia No. 9. Plants yielding non-seed carbohydrates. Prosea, Bogor.

Jata SK, Nedunchezhiyan M, Maity SK, Mallikarjun M. 2018. Intercrop and drip irrigation effects on growth, yield, water-use efficiency and economics of elephant foot yam (Amorphophallus paeoniifolius). Indian J Agro 63 (4): 506-512.

Jintan, Yuzammi, Suwastika IN, Pitopang R. 2015. Botany Amorphophallus paeoniifolius Dennst. Nicolson (Araceae) in Palu Valley. J Nat Sci 4(1): 17-31. [Indonesian]

Kite GC, Hetterscheid WLA. 2017. Phylogenetic trends in the evolution of inflorescence odours in Amorphophallus. Phytochemistry 142: 126-142.

Kuamr JS, More SJ, Byju G, Sunitha S, Veena SS, Nedunchezhiyan M, Ravi V. 2019. Effect of new generation herbicides on weed management, corm yield and economics of elephant foot yam [Amorphophallus paeoniifolius (Dennst.) Nicolson]. Inter J Chem Stud 7(3): 1213-1218.

Kurniawan A. Wibawa IPAH, Adjie B. 2011. Species diversity of Amorphophallus (Araceae) in Bali and Lombok with attention to genetic study in A. paeoniifolius (Dennst.) Nicolson. Biodiversitas 12(1): 7-11.

Mabhaudhi T. Modi AT Beletse YG. 2013. Response of taro (Colocasia esculenta $\mathrm{L}$. Schott.) landraces to varying water regimes under a rain shelter. Agric Water Manag 121: 102-112.

Mandal R. Nag S. Tarafdar J. Mitra S. 2016. A comparison of efficiency parameters of SSR markers genetic diversity analysis in Amorphophallus paeoniifolius (Dennst.) Nicolson. Braz Arch Biol Tech 59: 1-7

Martin GJ. 1995. Ethnobotany: A Method Manual. Chapman and Hall, London

Mutaqin AZ, Fatharani M, Iskandar J, Partasasmita, R. 2018. Utilization of Araceae by local community in Cisoka Village, Cikijing Subdistrict, Majalengka District, West Java, Indonesia. Biodiversitas 19(2): 560-571 
Newing H, Eagle CM, Puri RK, Watson CW. 2011. Conducting Research in Conservation: Social Science Methods and Practice. Routledge, London

Nugraha BSA, Widodo, Yuntara R, Normalita. 2018. Diversity of Angiospermae plant class Liliopsida in Mount Nglanggeran. Biol Med Nat Prod Chem 7(2): 45-49.

Cisoka Village Government. 2016. Profile of Cisoka Village, Cikijing District, Majalengka District. Cisoka Village Government, Majalengka [Indonesian]

Republic of Indonesia Government Regulation Number 37 of 2012 concerning Watershed Management

Permatasari M. Pitoyo A. Suratman. 2014. The diversity of suweg (Amorphophallus campanulatus) in the ex-residency area of Surakarta based on morphological, anatomical, and isozyme banding patterns. Bioteknologi 11(1): 11-18 [Indonesian]

Pratama A. 2011. Study of Pollination and Population of Amorphophallus variabilis Bl. [Skripsi]. Department of Biology Faculty of Mathematics and Natural Science University of Indonesia, Depok. [Indonesian]

Priyanti NA, Arubil A, Rumningtyas LE, Azrianingsih R. 2013. Analisis clustering varian Amorphophallus muelleri Blume yang ditemukan di Jawa Timur berdasarkan marka molekuler CsIA pengkode mannan synthase dengan teknik PCR-RFLP. Natural B 2(2): 122-127. [Indonesian]

Ramanathan R. Bhuvaneswari R. Indhu M. Subramanian G. Dhandapani R. 2014. Survey of ethnobotanical observation on wild tuberous medicinal plants of Kollihills, Namakkal district, Tamilnadu. J Mec Plants Studies 2(4): 50-58

Ravi V, Ravindran CS, and Suja G. 2009. Growth and productivity of elephant foot yam (Amorphophallus paeoniifolius (Dennst.) Nicolson: an overview. J Root Crops 35(2): 131-142.

Ravi V, Ravindran CS, Suja G, George J, Nedunchezhiyan M, Byju G, Naskar SK. 2011. Crop physiology of elephant foot yam (Amorphophallus paeoniifolius (Dennst.) Nicolson). Adv Hort Sci 25(1): 51-63.

Ravi V, Suja G, George J, Nedunchezhiyan M, Saravanan R, Byju G. 2015. Critical periode of crop sensitivity to water deficit stress in elephant foot yam (Amorphophallus paeoniifolius). Indian J Agri Sci 85(2): 126-129.

Restiyadi A. 2012. Recontemplation of the consumption of tubers as alternative food in deep agriculture archeology. In: Soedewo E, Susilowati N, Koestoro LP, Wiradnyana K, Oetomo RW, Nasoichah C, Setiawan T (eds). Balai Arkeologi Medan, Medan. [Indonesian]

Sahoo B, Nedunchezhiyan M, Acharyya P. 2016. Yield potential and economics of elephant foot yam (Amorphophallus paeoniifolius) as influenced by fertility levels, light interception, and soil resistance. Indian Agric 60 (1): 65-69.

Santosa E, Sugiyama N, Sulistyono E, Sopandie D. 2004. Effects of watering frequency on the growth of elephant foot yam. Japan J Trop Agric 48: 235-239

Santosa E, Mine Y, Nakata M, Lian C, Sugiyama N. 2010. Genetic Diversity of cultivated elephant foot yam (Amorphophallus paeoniifolius) in Kuningan, West Java as revealed by microsatellite markers. J App Hortic 12 (2): 125-128

Santosa E, Sugiyama N, Kawabata S, Hikosaka S. 2012. Genetic variations of Amorphophallus variabilis Blume (Araceae) in Java using AFLP. J Agron Indonesia 40(1): 62-68. [Indonesian]

Santosa E, Susila AD, Lontoh Ap. 2014. KNO3 application delays dormancy in the iles-iles plant (Amorphophallus muelleri Blume) Proceedings of the National Seminar on the Indonesian Agronomy Association. Prodi Agronomi Pascasarjana Universitas Sebelas Maret. Surakarta, 13-14 November 2014. [Indonesian]

Santosa E. Lian CL, Sugiyama N, Misra RS, Boonkorkaew P, Thanomchit K. 2017. Population structure of elephant foot yams (Amorphophallus paeoniifolius (Dennst.) Nicolson) in Asia. PLoS ONE 12 (6) e0180000. DOI: 10.1371/journal.pone.0180000
Santosa E, Lian CL, Mine Y, Takahata K, Sugiyama N. 2018. Isolating microsatellite from Amorphophallus variabilis and its application for population study in Dramaga Conservation Forest, Indonesia. Biotropia 25(1): 22-32

Sedayu A, Eurlings MCM, Gravendeel B, Hetterscheid WLA. 2010. Morphological character evolution of Amorphophallus (Araceae) based on a combined phylogenetic analysis of $\operatorname{trn} \mathrm{L}, r b \mathrm{~L}$, and LEAVY second intron sequences. Bot Stud 51: 473-490.

Simamora JM, Hikmat A, Zuhud EAM. 2017. The effect of biotic and physical environmental factors on total individual of Rafflesia meijerii in Batang Gadis National Park. Media Konservasi 22(1): 35-41 [Indonesian]

Singh B, Tham BBT, Rabha NN. 2010. Taxonomical notes on Amorphophallus paeoniifolius (Dennst.) Nicolson var. campanulatus (Decne) Sivadasan (gigantic flower): A new record for Meghalaya. J Econ Taxon Bot 34(3): 492-492

Singh A, Wadhwa N. 2014. A review on multiple potential of Aroid: Amorphophallus paeoniifolius. Inter J Pharm Sci Rev Res 24(1): 5560 .

Siswanto B, Karamina H. 2016. Porang crop land requirements (Amorphophallus oncophyllus). Buana Sains 16(1): 57-70. [Indonesian]

Sulistiyo RH, Soetopo L, Damanhuri. 2015. Exploration and identification morphological character of elephant foot yam (Amorphophallus muelleri B.) in East Java. J Produksi Tanaman 3(5): 353-361. [Indonesian]

Supriati Y. 2016. Biodiversity of Iles-iles (Amorphophallus spp.) and its potency for functional food, cosmetics, and bioethanol industries. J Litbang Pertanian 35 (2): 69-80 [Indonesian]

Toledo VM. 2002. Ethnoecology: a conceptual framework for the study of indigenous knowledge of nature. in Stepp JR, Wyndham FS, Zarger RK (eds) Ethnobiology and biocultural. The International Society of Ethnobiology, Georgia

Walujo EB. 2011. Ethnobotany science contribution in facilitating human relations with plants and their environment. J Biol Indonesia 7 (2): 375-391 [Indonesian]

Whitney CW, Min VS, Giang LH, Can VV, Barber K, Lanh TT. 2016. Learning with elders: Human ecology and ethnobotany explorations in Northern and Central Vietnam. Spring 75(1): 71-86.

Whitney CW, Bahati J, Gebauer J. 2018. Ethnobotany and agrobiodiversity: valuation of plants in the homegardens of Southwestern Uganda. Ethnobiol Lett 9(2): 90-100.

Wijayanto N, Pratiwi E. 2011. Shading influence of stand sengon (Paraserianthes falcataria (L.) Nilesen) on growth porang plants (Amorphophallus onchophyllus). J Silvikultur Tropika 02(01): 46-51. [Indonesian]

Yabesh JEM, Prabhu S, Vijayakumar S. 2014. An ethnobotanical study of medicinal plants used by traditional healers in silent valley of Kerala, India J Ethnopharm 154: 774-789.

Yuzammi, Witono JR, Hetterscheid WLA. 2014. Conservation status of Amorphophallus discophorus Backer \& Alderw. (Araceae) in Java, Indonesia. Reinwardtia 14(1): 27-33

Yuzammi, Kurniawan A, Asih NPS, Erlinawati I, Hetterscheid W. 2017. The Amorphophallus of Indonesia. Center for Plant Conservation Botanic Gardens, Indonesian Institute of Sciences, Bogor

Yuzammi. 2018. The diversity of aroids (Araceae) in Bogor Botanic Gardens, Indonesia: Collection, conservation and utilization. Biodiversitas 19(1): 140-152

Zambrana NYP, Leret RC, Bussmann RW, Macia MJ. 2014. The influence of socioeconomic factors on traditional knowledge: a crossscale comparison of palm use in Northwestern South America. Ecol Societ 19(4): 9

Zhang. D, Wang Q, George SS. 2010. Mechanism of staggered multiple seedling production from Amorphophallus bulbifer and Amorphophallus muelleri and its application to cultivation in Southeast Asia. Trop Agric Dev 54(3): 84-90. 